\title{
A New Proposal of Pelvic Floor Reconstruction Using Biosynthetic Mesh after Abdominoperineal Radical Surgery in Gynecological Cancer: A Case Series
}

\author{
Begoña Díaz de-la-Noval ${ }^{1 *}$, Ignacio Zapardiel ${ }^{1}$, Shirin Zarbaskhsh Etemandi², Alicia Hernández Gutiérrez ${ }^{1}$, Javier De- \\ Santiago García ${ }^{1}$ and Maria Dolores Diestro Tejeda ${ }^{1}$ \\ ${ }^{1}$ Gynecologic Oncology Unit; Department of Gynecology and Obstetrics. La Paz University Hospital, IdiPAZ, Madrid, Spain \\ ${ }^{2}$ Reconstructive Surgery Unit; Department of Plastic, Reconstructive and Aesthetic Surgery. La Paz University Hospital, IdiPAZ, Madrid, Spain
}

\section{Abstract}

Background: The purpose was to analyze the casuistry of pelvic floor reconstruction (PFR) with biological mesh (BM) after exenterative radical surgery.

Methods: Six patients treated with radical surgery and reconstruction of the perineal defect, conducted with a BM, since April 2011 to June 2016, are described.

Results: A total of 5 pelvic exenterations and an anterior pelvic supralevator exenteration were performed, 2 cases included a radical vulvectomy. In 5 patients the BM was placed intraoperatively, combined with myocutaneous bilateral gracilis flap or omentoplasty. Another case required deferred mesh placement due to evisceration through the perineal hole.

Mean surgical time was 510 minutes and a median hospitalization of 26 days. Complications were mainly due to infections and abdominal wall dehiscence. There were no pelvic organ prolapses and no mesh had to be removed. The mean follow-up was 8.5 months; halfof the patients are free of disease.

Conclusion: Though limited evidence, BM can be a safe and feasible option in cases of radical surgical gynecological procedures with a wide loss of soft tissue. More data is required.

\section{Background}

Abdominoperineal radical surgery in advanced or relapsed gynecological cancer produces a large perineal defect, requiring immediate and a complex pelvic floor reconstruction (PFR). Management of the pelvic floor is a critical step in the reconstructive phase of pelvic exenteration [1]. The empty pelvic dead space predisposes to abscesses, fistula, wound infection, bowel obstruction and perineal prolapse. The incidence of perineal prolapse is over $6 \%$ after an ultra-radical surgery. These complications are associated with increased hospital stay, reoperation, and low quality of life $[1,2]$.

There is no consensus about the optimal technique in PFR [2]. Current standards in PFR are myocutaneous flaps, alternatives are omentoplasty or breast implant. Omentoplasty is considered an alternative, but not enough to cover large defects; and autologous flaps do not prevent from perineal prolapse; though many cases require the combination of both procedures [2].

Improvements in surgical and reconstructive techniques over the last decades haveintroduced the use of biosynthetic meshes in complex procedures with promising results,improving wound healing and reducing perineal hernia rates [3]. The combination of different techniques may allow a successful management of large perineal defects [2].

There is validated experience, even though controversial, in its use for surgical reconstruction after abdominoperineal excision in anal or rectal cancer, being limited in gynecology oncology $[1,3]$. Our purpose was to analyze the casuistry of PFR with biological mesh (BM) after exenterative surgical procedures for gynecological cancer.

\section{Materials and Methods}

\section{Results}

\section{Publication History:}

Received: July 19, 2017

Accepted: October 07, 2017

Published: October 09, 2017

\section{Keywords:}

Female genital neoplasms, Gynecologic surgical procedures, Pelvic exenteration, Pelvic organ prolapse, Surgical mesh, Urogenital neoplasms

The institutional database is reviewed. We have done a retrospective analysis including 6 patients with primary or recurrent pelvic malignancies treated with radical surgery, and reconstruction of the perineal defect; conducted with the placement of a non-cross-linked porcine a cellular dermal matrix (StratticeTM Reconstructive Tissue Matrix, Allergan-LifeCell Corporation -New Jersey, EE.UU), since April 2011 to June 2016 at La Paz University Hospital - Madrid. The surgical procedure is explained in the attached video.

The current evidence published in PubMed about this topic is reviewed; further reading of the articles with the greatest impact published in the last 10 years. The statistical analysis was performed with program IBM SPSS Statistics v.22.0.

The median age was 56 years old (43-73). Five (83.3\%) patients were referred from hospitals in other Spanish regions. These patients had histologically an urothelial carcinoma, 2 epidermoid carcinomas of the vagina and 2 of the cervix, and 1 low-grade endometrial stromal

"Corresponding Author: Dr. Begoña Díaz de-la-Noval, Gynecologic Oncology Unit; Department of Gynecology and Obstetrics. La Paz University Hospital, IdiPAZ, Madrid, Spain, Tel: +34.616306566; E-mail: begodelanoval@gmail.com

Citation: de-la-Noval BD, Zapardiel I, Etemandi SZ, Gutiérrez AH, García JD (2017) A New Proposal of Pelvic Floor Reconstruction Using Biosynthetic Mesh after Abdominoperineal Radical Surgery in Gynecological Cancer: A Case Series. Int J Gynecol Clin Pract 4: 132. doi: https://doi.org/10.15344/2394-4986/2017/132

Copyright: (c) 2017 de-la-Noval et al. This is an open-access article distributed under the terms of the Creative Commons Attribution License, which permits unrestricted use, distribution, and reproduction in any medium, provided the original author and source are credited. 
Citation: de-la-Noval BD, Zapardiel I, Etemandi SZ, Gutiérrez AH, García JD (2017) A New Proposal of Pelvic Floor Reconstruction Using Biosynthetic Mesh after Abdominoperineal Radical Surgery in Gynecological Cancer: A Case Series. Int J Gynecol Clin Pract 4: 132. doi: https://doi.org/10.15344/2394-4986/2017/132

Page 2 of 6

sarcoma of the vagina. Fifty percent of the tumors were high-grade of histological differentiation. Initial treatment was radiotherapy in 3 cases and relapses were predominantly late (Table 1).

The cases present an extensive centropelvic involvement (mean tumor size of 88 [60-150] $\mathrm{mm}$ ), with infiltration of pelvic organs, vagina, and perineal floor, without clinical evidence of reaching the pelvic wall or pathological lymphadenopathy in the radiological study.

The surgical procedure performed was a total pelvic exenteration $(\mathrm{PE})$ in 5 cases ( 3 infralevator, 2 supralevator) and an anterior supralevator PE. In addition, 2 cases required radical vulvectomy, 4 had a bilateral pelvic lymphadenectomy and 2 a para-aortic sampling for suspected intraoperative lymphadenopathy. No case had metastatic lymph nodes. In 2 procedures, a laparoscopic-assisted gynecological approach was performed, the others by median xiphopubic incision.

In 5 patients the mesh was placed intraoperatively, in addition to a gracilis bilateral myocutaneous flap $(n=2)$ or omentoplasty $(n=2)$.
The surgical film included in this manuscript demonstrates the BM placement procedure in 2 of these patients (Figure 1)

The patient with an anterior PE (case number 6 in Table 1) had to be readmitted due to the small bowel and omentum evisceration through the perineal hole. An urgent surgical reduction was performed and the BM was placed attached to the perineum and levator ani muscle. In another case of cervical cancer relapse and supralevator posterior $\mathrm{PE}$ (not included in this cohort due to the deferred vulvoperineal reconstructive process), after 2 years free of disease, perineal reconstruction was performed with left rectus abdominis and bilateral pudendal myocutaneous flaps, no mesh was placed. Six months later, due to the lack of pelvic support, both pudendal flaps prolapsed.

Five (83.3\%) patients obtained clear surgical margins. Regarding the adjuvant treatment, the patient with affected margins received perioperative interstitial radiotherapy, another 2 patients received chemotherapy, one patient received external radiation therapy and 2 had no adjuvant therapy due to postoperative complications.

\begin{tabular}{|c|c|c|c|c|c|c|c|c|c|c|c|}
\hline $\mathrm{n}$ & $\begin{array}{c}\text { Age } \\
\text { (years) }\end{array}$ & $\begin{array}{l}\text { Primary } \\
\text { Carcinoma }\end{array}$ & $\begin{array}{c}\text { Stage at } \\
\text { diagnosis }\end{array}$ & Initial Therapy & $\begin{array}{l}\text { Time to } \\
\text { recurrence }\end{array}$ & Surgery & $\begin{array}{c}\text { Pelvic } \\
\text { Reconstruction }\end{array}$ & Complications & Adjuvancy & $\begin{array}{l}\text { Follow-up } \\
\text { (months) }\end{array}$ & Status \\
\hline 1 & 43 & $\begin{array}{l}\text { Squamous } \\
\text { Cervical } \\
\text { Carcinoma G1 }\end{array}$ & IIB & $\begin{array}{l}\text { Radical } \\
\text { hysterectomy and } \\
\text { Bilateral PL } \\
\text { Adjuvant RT. }\end{array}$ & 27 years & $\begin{array}{l}\text { Total Supralevator } \\
\text { Pelvic Exenteration } \\
\text { by laparotomy } \\
\text { bilateral PL Para- } \\
\text { aortic lymph-node } \\
\text { sampling }\end{array}$ & Biological Mesh & $\begin{array}{l}\text { Abdominopelvic } \\
\text { Abscess } \\
\text { Abdominal wall } \\
\text { dehiscence } \\
\text { Urinary tract } \\
\text { obstruction }\end{array}$ & $\begin{array}{l}\text { Perioperative } \\
\text { Interstitial } \\
\text { Brachytherapy }\end{array}$ & 10.9 & $\begin{array}{l}\text { Deceased (local } \\
\text { relapse before } \\
\text { one year since } \\
\text { exenteration) }\end{array}$ \\
\hline 2 & 73 & $\begin{array}{l}\text { Endometrial } \\
\text { Stromal } \\
\text { Sarcoma } \\
\text { G1 }\end{array}$ & IVA & $\begin{array}{l}\text { Two procedures } \\
\text { for local exeresis }\end{array}$ & 7 months & $\begin{array}{l}\text { Total Supralevator } \\
\text { Pelvic Exenteration } \\
\text { by laparotomy }\end{array}$ & $\begin{array}{l}\text { Bilateral Gracilis } \\
\text { Myocutaneous } \\
\text { Flap + Biological } \\
\text { Mesh }\end{array}$ & $\begin{array}{l}\text { Abdominal } \\
\text { Abscess } \\
\text { Abdominal wall } \\
\text { dehiscence } \\
\text { Abdominal wall } \\
\text { Cellulitis } \\
\text { Pneumonia } \\
\text { Septic Shock and } \\
\text { MOF } \\
\text { PTE }\end{array}$ & No & $\begin{array}{l}\text { Deceased of } \\
\text { postoperative } \\
\text { complications }\end{array}$ & Deceased \\
\hline 3 & 63 & $\begin{array}{l}\text { Squamous } \\
\text { Vaginal } \\
\text { Carcinoma } \\
\text { G3 }\end{array}$ & II & RT & 20 years & $\begin{array}{l}\text { Total Infralevator } \\
\text { Pelvic Exenteration } \\
\text { by laparotomy } \\
\text { Bilateral PL } \\
\text { Vulvectomía } \\
\text { Simple }\end{array}$ & $\begin{array}{l}\text { Epiploplasty + } \\
\text { Biological Mesh }\end{array}$ & $\begin{array}{l}\text { Femoral nerve } \\
\text { neuropathy (L2- } \\
\text { L3-L4 lumbar } \\
\text { plexus) }\end{array}$ & CT & 2 & Free of disease \\
\hline 4 & 46 & $\begin{array}{l}\text { Squamous } \\
\text { Vaginal } \\
\text { Carcinoma }\end{array}$ & I & RT & 24 months & $\begin{array}{l}\text { Laparo-assisted } \\
\text { Total Infralevator } \\
\text { Pelvic Exenteration } \\
\text { Radical Vulvo- } \\
\text { vaginectomy }\end{array}$ & $\begin{array}{l}\text { Bilateral Gracilis } \\
\text { Myocutaneous } \\
\text { Flap + Biological } \\
\text { Mesh }+ \\
\text { Neovagina }\end{array}$ & $\begin{array}{l}\text { Flap ischemia } \\
\text { Abdominopelvic } \\
\text { Abscesses }\end{array}$ & $\begin{array}{l}\text { Not possible } \\
\text { because of } \\
\text { postoperative } \\
\text { complications }\end{array}$ & 13.3 & $\begin{array}{l}\text { Deceased } \\
\text { (local relapse } \\
\text { and metastatic } \\
\text { disease before } \\
\text { one year since } \\
\text { exenteration) }\end{array}$ \\
\hline 5 & 67 & $\begin{array}{l}\text { Squamous } \\
\text { Cervical } \\
\text { Carcinoma } \\
\text { G2 }\end{array}$ & IBI & RT & 32 years & $\begin{array}{l}\text { Total Supralevator } \\
\text { Pelvic Exenteration } \\
\text { by laparotomy } \\
\text { Bilateral PL } \\
\text { Para-aortic lymph- } \\
\text { node sampling } \\
\text { Radical Vulvo- }\end{array}$ & Biological Mesh & $\begin{array}{l}\text { Femoral nerve } \\
\text { neuropathy (L2- } \\
\text { L3-L4 lumbar } \\
\text { plexus) }\end{array}$ & RT & 9.5 & Free of disease \\
\hline 6 & 44 & $\begin{array}{l}\text { Urothelial } \\
\text { Carcinoma } \\
\text { Undifferentiated }\end{array}$ & T4N0M0 & $\begin{array}{l}\text { Initial suspicion } \\
\text { of gynecologic } \\
\text { sarcomatoid } \\
\text { tumor type with } \\
\text { involvement of } \\
\text { the anterior pelvis } \\
\text { and associated } \\
\text { deep pelvic } \\
\text { endometriosis. }\end{array}$ & No relapse & $\begin{array}{l}\text { Laparo-assisted } \\
\text { Anterior } \\
\text { Supralevator Pelvic } \\
\text { Exenteration } \\
\text { End-to-End } \\
\text { Ileocecal } \\
\text { Anastomosis } \\
\text { Bilateral PL }\end{array}$ & $\begin{array}{l}\text { Epiploplasty }+ \\
\text { Biological Mesh }\end{array}$ & $\begin{array}{l}\text { Evisceration } \\
\text { Abdominopelvic } \\
\text { Abscesses } \\
\text { Urinary } \\
\text { infection } \\
\text { Bilateral } \\
\text { Nephrostomy } \\
\text { due to Bricker } \\
\text { obstruction } \\
\text { Adynamic ileus } \\
\text { Pleural effusion }\end{array}$ & CT & 7 & Free of disease \\
\hline
\end{tabular}

Table 1: Description of tumor characteristics for each patient.

Abbreviations: G - degree of tumor histological differentiation, PL - pelvic lymphadenectomy, MOF - multi-organ failure, PTE - pulmonary thromboembolism, CT chemotherapy, RT - radiotherapy. 
Citation: de-la-Noval BD, Zapardiel I, Etemandi SZ, Gutiérrez AH, García JD (2017) A New Proposal of Pelvic Floor Reconstruction Using Biosynthetic Mesh after Abdominoperineal Radical Surgery in Gynecological Cancer: A Case Series. Int J Gynecol Clin Pract 4: 132. doi: https://doi.org/10.15344/2394-4986/2017/132

\section{A new proposal of Pelvic Floor Reconstruction with a Biological Mesh after Abdominoperineal Radical Surgery in Gynecological Cancer.}

B Diaz-de la Noval, I Zapardiel, S Zarbashkh,

A Hernández, J De Santiago, MD Diestro.

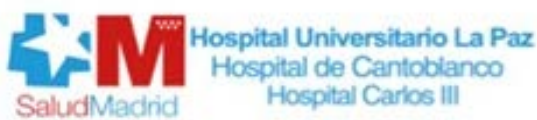

Figure 1: Videocover.

The surgical film demonstrates the biological mesh placement procedure in 2 of the patients described.

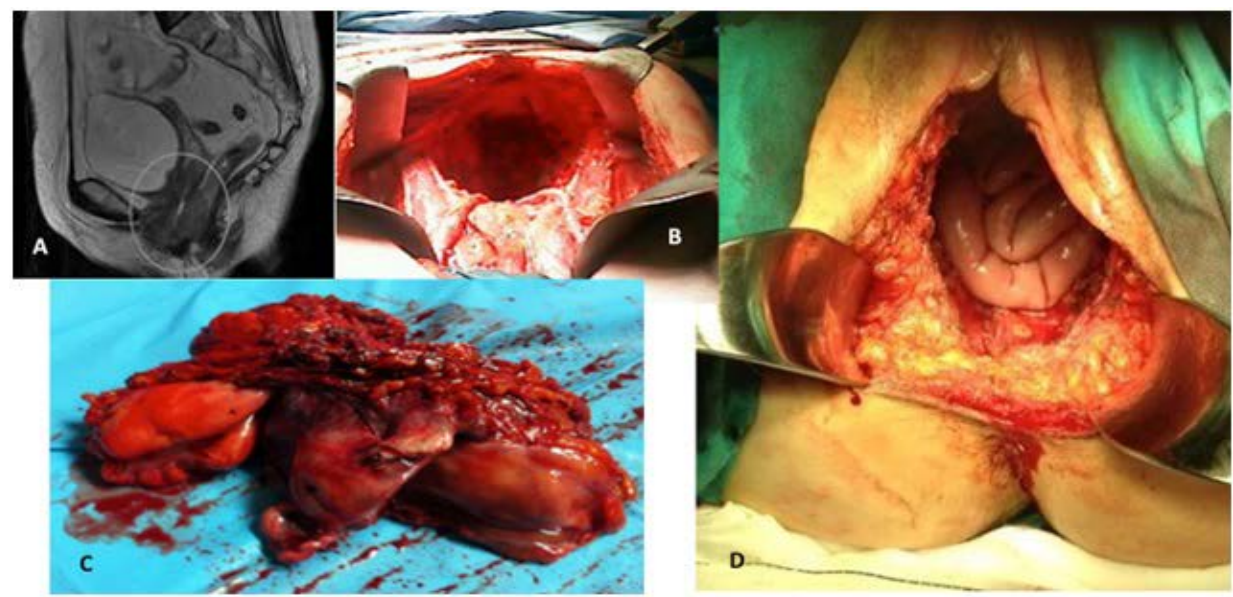

Figure 2: "TheEmpty Pelvis Syndrome".

(A) CT image of a cervical carcinoma centropelvic relapse with perineal, rectum and bladder invasion. (B) Transabdominal view of the empty pelvis after a total exenteration. (C) En-block tumor specimen of a supralevator total exenteration. (D) Transperineal view of the empty pelvic cavity.

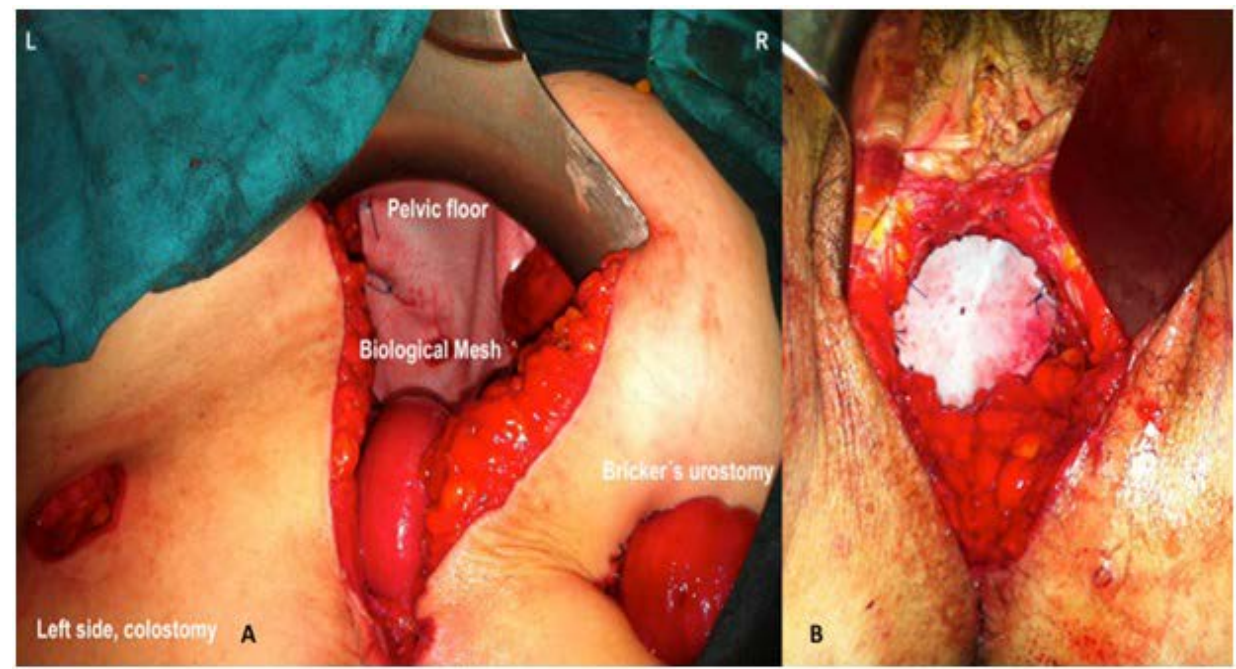

Figure 3: Different approaches for biological mesh placement.

(A)Transabdominal placement of a biological mesh in a patient undergoing total supralevator pelvic exenteration in a centropelvic recurrence of a vaginal carcinoma treated with radiotherapy. (B) Perineal view after pelvic mesh fixation with non-absorbable $2 / 0$ polypropylene suture. 
Complications were mainly recurrent pelvic abscesses and abdominal wall dehiscence; no pelvic organ prolapsed and no mesh had to be removed. Abscesses were treated with antibiotics and/or image-guided drainage. Abdominal wall dehiscence received initially conservative management, surgical repair if symptoms persist. The mean operative time was 510 (365-715)minutes, and median hospitalization was 26 [16-34] days.

The mean follow-up was 8.5 months [2-13.3]. Half of the patients do not present evidence of disease at the time of this research. Two (33.3\%) patients died due to local relapse and distant metastases in an early onset (11.5 months), they disease advanced even with systemic treatment; another patient did not recover from complications after surgery.

\section{Discussion}

Abdominoperineal radical surgery procedure is the only curative option in patients with locally advanced or relapsed pelvic cancersafter radiotherapy, chemoradiation, and/or primary surgery [3]. The enblock resection of the pelvic organs together with a portion of the pelvic diaphragm leaves a large hole in the pelvic floor [2]. This wide perineal defect requires complex pelvic floor reconstruction (PFR). Reconstruction phase requires not only the derivation of the urinary and digestive tract, also a careful perineal closure and according to the patient's desire a neo-vagina [4].

“The Empty Pelvis Syndrome" refers to an empty space or cavity following pelvic exenteration (Figure 2), which may result in complications as small bowel obstruction, fistula formation, visceral or perineal herniation, recurrent pelvic abscesses, hematoma or lymphocele [1,4]; leading to chronic discharge and infections [5]. The incidence of fistula is estimated in $15 \%$ of cases [1] and perineal prolapse is over $6 \%$ to $21 \%$ after an ultra-radical surgery [6,7] These complications are associated with increased hospital stay, reoperation, low quality of life $[8,9]$ and carry a high mortality rate [1] Management of these complications and psychological consequences can be difficult to cure, but it can be prevented.

In a recent retrospective analysis published by our Gynecologic Oncology Unit, that included patients treated with PE for recurrent gynaecologic malignancies, we studied the most favorable prognostic factors for a positive outcome after radical surgery. These factors were free surgical margins, no lymph node involvement and adequate pelvic reconstruction [10]. Chiantera et al. [3] performed a retrospective study in 230 patients who underwent PE for primary or recurrent gynecological malignancies, analyzing the morbidity and postoperative mortality. Almost half of the patients had complications, being more frequent in patients older than 60 years $(\mathrm{P}=0.077)$ Themajor complication rate was $21.3 \%$, mainly related to abdominal infections and the reconstructive surgery complications (17\% wound dehiscence, $20.4 \%$ colorectal anastomosis complications, $11.3 \%$ urinary obstruction and $33.3 \%$ vulvar flap necrosis or dehiscence).

There is no consensus about the optimal technique in PFR [9]. The main aim of fill in the pelvic floor is to keep the bowel out of a potentially infected pelvic floor [1].Current procedures in PFR are mainly myocutaneous flaps (rectus abdominis, latissimus dorsi, tensor fasciae late, gluteal or gracilis muscle) and omentoplasty is considered an alternative $[2,11]$. Some authors like Sugarbaker [12] or Schmitz et al. [13] used breast prosthesis to fill in the pelvis. Other mentioned procedures are the use of dura mater, peritoneum flap, sigmoid-colon lid and different vaginal reconstruction techniques [1].The omental flap was introduced to fill the empty pelvic cavity and to prevent early and late small intestinal complications, mainly in irradiated pelvis [11]. Omentoplasty advantages are local control of infection/ abscesses, reduction of local morbidity and prevention from perineal fistula, but it is not enough to cover large defects and avoid the perineal hernia.Also, autologous flaps, despite good outcomes, do not prevent perineal prolapse $[2,8]$. The use of a biosynthetic mesh (BM), in complex perineal defects, has comparable complications rates as myocutaneous flaps, improving wound healing and reducing perineal hernia rates, with considerable less morbidity [14]. The combination of different techniques in PFR is suitable and may allow a successful management $[2,9]$.

The biosynthetic mesh acts as a physical barrier, which supports the pelvic contents and minimizes pressure on the perineal area [9]. There are two types of meshes: biological (BM) and synthetic. Both have same properties and durability, although the biological has better tissue biocompatibility and fewer complications [15].BMs are composed of human or porcine acellular dermal, totally resorbable; these are the most popular. Non-crosslinked BM allows earlier integration into the tissue and diminishes infections [16]. The acellular biological collagen of the mesh is gradually absorbed within 4-6months and integrates the patient's own collagen creating a new fascia-like tissue with adequate tensile strength as a diaphragm [14]. Synthetic meshes are made of polypropylene or polyglactin. Non-resorbable synthetic meshes are associated with more complications (infection, extrusion, adhesions and foreign body reactions); therefore, are rarely used [2,9] and usually covered with the omentum to prevent from adhesions [1].

The main utility of the BM is to create a physical barrier that supports and isolates the pelvic cavity, reducing the main complications of "The Empty Pelvis Syndrome". Different techniques have been described on how to place the mesh, without a differentiation for the type of mesh (Figure 3) [16]. The use of interrupted polypropylene non-absorbable suture points is preferred [16] to help reduce the seroma formation [18]; despite the fact that other authors use slow absorption sutures. Drains can be placed over the mesh if necessary, and antibiotics should be kept at least 3 more days [7].

The BM is associated with lower rates of complications andimproved perineal wound healing than synthetic meshes, providing a durable structural support [17]. Few complications are described related to $\mathrm{BMs}$, including infection, perineal fistula, chronic pelvic pain, mesh migration or cutaneous exposure, perineal prolapse and adhesions $[10,15]$. Reported data is not very accurate, because the evidence available has a short follow-up, and no paper included patients with gynecological cancer.In our cohort, no mesh had to be removed and there were no perineal hernias. Harries et al. [18] reported 48 patients with extralevator abdominoperineal excision of the rectum (ELAPER) for rectal carcinoma, with no perineal wound herniae after mesh placement during a mean follow-up of 27 months. Peacock et al. [19] included 34 patients after ELAPER and perineal reconstruction with BM without the additional use of myocutaneous flaps. During a mean follow-up of 21 months, no mesh was removed, with only 3 cases (9\%) of major complications (wound collections/abscesses) that required surgical drainage and vacuum-assisted closure (VAC). In Musters et al. [20] response to Jensen et al. single-center experience report, the lack of a comparative group is criticized. Also, conclusions are favorable to $\mathrm{BM}$, despite the fact that non-infectious complication rate was $55 \%$ and re-operation rate of $28 \%$, extremely high to finally 
Citation: de-la-Noval BD, Zapardiel I, Etemandi SZ, Gutiérrez AH, García JD (2017) A New Proposal of Pelvic Floor Reconstruction Using Biosynthetic Mesh after Abdominoperineal Radical Surgery in Gynecological Cancer: A Case Series. Int J Gynecol Clin Pract 4: 132. doi: https://doi.org/10.15344/2394-4986/2017/132

Page 5 of 6

conclude the support of the routine use of biological mesh in PFR. Musters et al. had recently completed enrollment of the BIOPEXstudy [8], the first randomized controlled multicenter study with BM for perineal wound closure in abdominoperineal resection in rectal carcinoma, final results are pending publication.

A drawback is that the $\mathrm{BM}$ is more expensive, but the global cost is lesser than using flaps. A recent systematic review evaluating perineal reconstruction following ELAPER showed no significant differences in complication rates between $\mathrm{BM}$ and myocutaneous flap for PFR [21]. Costsaving with BMis reflected in many benefits: earlier patient mobilization, reduced hospital stay, shorter operative time, less reintervention, fewer infection and abscesses, no donor complications, and a short learning curve with less need for a reconstructive team during surgery $[2,7-9]$.

As mentioned, there is a lack of consensus about the recommended technique for PFR. According to our brief experience and after reviewing the literature on this subject, it is advisable to use a cellula dermal BM for its better biocompatibility and fewer complications, especially infectious and perineal prolapses; without proven differences over other techniques.

The high mortality (50\%) is usually associated with the clinical situation, adding a radical surgical procedure. Given the surgical complexity, it is difficult to differentiate whether the events occurring are due to the mesh or not. Because of the low number of case and events, we cannot lead to safe conclusions; but given the good experience discussed; they may be inherent to the clinical situation.

We know that our strength of evidence is low due to the recent introduction of this technique along with a low case series and short follow-up time. Although there is already experience in radical perineal surgery for anus-rectal cancers, our short report is so far one ofthe first articles in the use of $\mathrm{MB}$ in patients with gynecological cancer, excluding case reports [17]. Therefore, we suggest collaboration for the development of a multicenter study that will get better evidence.

\section{Conclusion}

In conclusion, even though there is still insufficient evidence in its application in gynecological cancer, absorbable BM can be a safe and feasible option, either isolated or in combination with other alternatives (omentoplasty, myocutaneous flaps or prosthetic implant), in cases of radical surgical procedures with a wide loss of soft tissue. More data and long-term outcomes are required to identify patients who would benefit most.

\section{Competing Interests}

The authors declare that they have no competing interests.

\section{Author Contributions}

B Diaz de la Noval: project development, manuscript writing/ editing, manuscript reviewer, literature searchand final approval of manuscript.

I Zapardiel: manuscript writing, manuscript reviewer and final approval of manuscript.

$S$ Zarbakhsh Etemandi: manuscript reviewer and final approval of manuscript.
A Hernandez Gutierrez: manuscript reviewer and final approval of manuscript.

J De-Santiago Garcia: project development, manuscript reviewer and final approval of manuscript.

MD Diestro Tejeda: project development, manuscript writing, manuscript reviewer and final approval of manuscript.

\section{References}

1. Pálfalvi $L$ (1998) Reconstruction of the pelvic floor and management of the empty pelvis; correction of pelvic hernias. Nögyógyászati Onkológia 2: 175176

2. Eleonora F, Luca V, Franco B, Bruno C, Lorenzo C, et al. (2013) Combination of omentoplasty, trans-abdominal biological mesh, and vacuum-assisted closure system for complex pelvic floor reconstruction. An alternative to current standards? Int J Colorectal Dis 28:1729-1730.

3. Chiantera V, Rossi M, De laco P, Koehler C, Marnitz S, et al. (2014) Morbidity after pelvic exenteration for gynecological malignancies:a retrospective multicentric study of 230 patients. Int J Gynecol Cancer 24: 156-164

4. Bacalbasa N, Filipescu A, Balescu I (2014) Total pelvis exenteration as a potentially curative surgical procedure in locally advanced gynecologic malignancy. Gineco.eu Journal 10: 78-79.

5. Ghosh PS, Fawzi H (2004) Empty pelvis syndrome. J Obstet Gynaeco 24: 714-715.

6. Jensen KK, Rashid L, Pilsgaard B, Møller P, Wille-Jørgensen P (2014) Pelvic floor reconstruction with a biological mesh after extralevato abdominoperineal excision leads to few perineal hernias and acceptable wound complication rates with minor movement limitations: single-centre experience including clinical examination and interview. Colorectal Dis 16: 192-197.

7. Christensen HK, Nerstrøm P, Tei T, Laurberg S (2011) Perineal repair after extralevator abdominoperineal excision for low rectal cancer. Dis Colon Rectum 54: 711-717.

8. Musters GD, Bemelman WA, Bosker RJ, Burger JW, van Duijvendijk P, et al. (2014) Randomized controlled multicenter study comparing biological mesh closure of the pelvic floor with primary perineal wound closure after extralevator abdominoperineal resection for rectal cancer (BIOPEX-study). BMC Surg 14: 58

9. Alam NN, Narang SK, Köckerling F, Daniels IR, Smart NJ (2016) Biologic Mesh Reconstruction of the Pelvic Floor after Extralevator Abdominoperineal Excision: A Systematic Review. Front Surg 3: 1-8.

10. Moreno-Palacios E, Diestro MD, De Santiago J, et al. (2015) Pelvic Exenteration in Gynecologic Cancer. Int J Gynecol Cancer 25: 1109-1114.

11. De Wever I (2011) Pelvic exenteration: surgical aspects and analysis of early and late morbidity in a series of 106 patients. Acta Chir Belg 111 273-281.

12. Sugarbaker PH (1983) Intrapelvic prosthesis to prevent injury of the smal intestine with high dosage pelvic irradiation. Surg Gynecol Obstet 157: 269271.

13. Schmitz RL, Schmitz HE, Smith CJ, Molitor JJ (1960) Details of pelvic exenteration evolved during an experience with 75 cases. Am J Obstet Gynecol 80: 43-52.

14. Wille-Jørgensen P, Pilsgaard B, Møller P (2009) Reconstruction of the pelvic floor with a biological mesh after abdominoperineal excision for rectal cancer. Int J Colorectal Dis 24: 323-325.

15. Han JG, Wang ZJ, Gao ZG, Xu HM, Yang ZH, et al. (2010) Pelvic floor reconstruction using human acellular dermal matrix after cylindrical abdominoperineal resection. Dis Colon Rectum 53: 219-223.

16. Svane M, Bulut O (2012) Perineal hernia after laparoscopic abdominoperineal resection- reconstruction of the pelvic floor with a biological mesh (PermacolTM). Int J Colorectal Dis 27: 543-544.

17. Said HK, Bevers M, Butler CE (2007) Reconstruction of the pelvic floor and perineum with human acellular dermal matrix and thigh flaps following pelvic exenteration. Gynecologic Oncology 10: 578-582. 
Citation: de-la-Noval BD, Zapardiel I, Etemandi SZ, Gutiérrez AH, García JD, (2017) A New Proposal of Pelvic Floor Reconstruction Using Biosynthetic Mesh after Abdominoperineal Radical Surgery in Gynecological Cancer: A Case Series. Int J Gynecol Clin Pract 4: 132. doi: https://doi.org/10.15344/2394-4986/2017/132

Page 6 of 6

18. Harries RL, Luhmann A, Harris DA, Shami JA, Appleton BN (2014) Prone extralevator abdominoperineal excision of the rectum with porcine collagen perinea reconstruction (Permacol ${ }^{\mathrm{TM}}$ ): high primary perineal wound healing rates. Int J Colorectal Dis 29: 1125-1130.

19. Peacock O, Simpson JA, Tou SI, Hurst NG, Speake WJ, et al. (2014) Outcomes after biological mesh reconstruction of the pelvic floor following extra-levator abdominoperineal excision of rectum (APER). Tech Coloproctol 18: 571-577.

20. Jensen KK, Rashid L, Pilsgaard B, Møller P, Wille-Jørgensen P (2014) (2014) Response to: Pelvic floor reconstruction with a biological mesh after extralevator abdominoperineal excision leads to low wound complications and perineal hernia rates with minor movement limitations. Colorectal Dis 16: $563-564$

21. Foster JD, Pathak S, Smart NJ, Branagan G, Longman RJ, et al. (2012) Reconstruction of the perineum following extralevator abdominoperineal excision for carcinoma of the lower rectum: a systematic review. Colorecta Dis 14: 1052-1059.

This article was originally published in a special issue

Gynecology \& Surgical Oncology

Handled by Editor(s):

Dr. Maria Teresa Gomez Garcia

Department of Medical Sciences

University of Castile-La Mancha

Spain 